\title{
A!
}

This is an electronic reprint of the original article.

This reprint may differ from the original in pagination and typographic detail.

Uotinen, L.K.T.; Salo, O.; Rinne, M.

\section{Design of sprayed concrete as hard rock reinforcement using yield-line theory}

\section{Published in:}

Rock Characterisation, Modelling and Engineering Design Methods - Proceedings of the 3rd ISRM SINOROCK 2013 Symposium

Published: 01/01/2013

Document Version

Peer reviewed version

Please cite the original version:

Uotinen, L. K. T., Salo, O., \& Rinne, M. (2013). Design of sprayed concrete as hard rock reinforcement using yield-line theory. In Rock Characterisation, Modelling and Engineering Design Methods - Proceedings of the 3rd ISRM SINOROCK 2013 Symposium (pp. 817-822). CRC Press.

This material is protected by copyright and other intellectual property rights, and duplication or sale of all or part of any of the repository collections is not permitted, except that material may be duplicated by you for your research use or educational purposes in electronic or print form. You must obtain permission for any other use. Electronic or print copies may not be offered, whether for sale or otherwise to anyone who is not an authorised user. 


\title{
Design of sprayed concrete as hard rock reinforcement using yield-line theory
}

\author{
L.K.T. Uotinen \\ Aalto University, Espoo, Finland \\ O. Salo \\ Saanio \& Riekkola Oy, Helsinki, Finland \\ M. Rinne \\ Aalto University, Espoo, Finland
}

\begin{abstract}
Yield-Line Theory (YLT) has been in wide spread use since the 1960's. YLT allows determining of the upper-bound bending resistance of reinforced concrete slabs using the concept of virtual work. YLT can be used for two purposes in the design of sprayed concrete support: the determination of quality assurance demands for the sprayed concrete or in the design of adequate sprayed concrete layer thickness against a bending failure. The square slab energy absorption test (EN 14488-5) and the round panel flexural toughness test (ASTM C1550-12a) are used. Solutions for both tests are given and conversion equations are derived. Testing results produced during normal quality assurance testing process in Länsimetro project (Finland) are shown for comparison. Finally, the merits and draw-backs of the test types are discussed.
\end{abstract}

\section{INTRODUCTION}

\subsection{History}

As long ago as 1908, the Danish codes for reinforced concrete structures specified a beam analysis that can be characterized as a modified yield-hinge theory, and in 1921, the Yield-Line Theory (YLT) for slabs proposed by Danish engineer Aage Ingerslev came into use. (Johansen 1972) In 1931, Knud Windstrup Johansen gave the concept a geometrical meaning as lines of relative rotation of rigid slab parts. (Braestrup 2007) In 1943, Johansen published his thesis Brudlinietheorier (Yield-line theory) in Danish. 19 years later it was translated into English and released as Yield-line theory (Johansen 1962), which is the recommended source for the reader.

\subsection{Yield-line theory}

The term "yield-line" (brudlinie) was coined by Ingeslev in 1921 to describe lines in the slab along which the bending moment is constant. (Braestrup 2007) According to Holmgren (1993) reinforced concrete slabs are normally designed using YieldLine Theory. The YLT is a widely used method in order to determine the bending resistance of reinforced concrete slabs.

YLT is an upper bound method to determine the plastic moment resistance using the concept of virtual work. The slab is divided into rotating parts by yielding regions which are approximated as yieldlines and the virtual work is calculated for both internal and external actions. The sum of these virtual works must be zero to maintain equilibrium. When the yield-lines are fully developed, the slab becomes a mechanism and fails.

\subsection{Applicability}

According to European Standard (EN) 14487-1:2006 the limiting values for composition set in EN 2061:2000 for concrete apply for sprayed concrete, with two exceptions: the minimum cement content is $300 \mathrm{~kg} / \mathrm{m}^{3}$ and the minimum air content requirement is not applicable. Experimental data from quality assurance testing in rock engineering projects in Finland support the practice, that the same strength equations can be used for both sprayed concrete (shotcrete) and cast concrete.

The strength equations of Eurocode 2 (EN 1992-1$1: 2004)$ derive strength parameters from the uniaxial compressive strength (UCS) of the concrete. The concrete grade is specified using the notation, "C35/45" where the first number is the characteristic uniaxial compressive cylinder (300 mm x $\varnothing 100 \mathrm{~mm}$ ) strength of concrete at 28 days in MPa $\left(f_{c k}\right)$ and the latter number is the corresponding cube $(150 \mathrm{~mm} \mathrm{x}$ $150 \mathrm{~mm} \times 150 \mathrm{~mm}$ ) uniaxial compressive strength $\left(f_{\text {ck, cube }}\right)$.

\subsection{EN 14488-5 square slab test}

In 1999, The Experts for Specialised Construction and Concrete Systems (EFNARC) presented a square slab test for energy absorption. Later a 
modified version of this was included as a part of the European Standards regulating sprayed concrete testing. The EN slab test should not be referred as the EFNARC slab test as the test descriptions are not identical.

The EN 14488-5 test uses a $600 \mathrm{~mm} \times 600 \mathrm{~mm} \times$ $100 \mathrm{~mm}$ square slab which rests on a continuous free support with internal dimensions of $500 \mathrm{~mm} \mathrm{x}$ $500 \mathrm{~mm}$ (Fig. 1a). The slab is loaded centrally using a $100 \mathrm{~mm} \times 100 \mathrm{~mm} \times 20 \mathrm{~mm}$ steel plate and the load-deflection curve is recorded until the deflection reaches $30 \mathrm{~mm}$. Corner uplift is not constrained and the steel plate is allowed to rotate and/or tilt.

\subsection{C1550 round panel test}

The first round panel test similar to the C1550 configuration was undertaken in 1997 as part of an investigation of the influence of support conditions on structural behavior in fibre reinforced concrete panels. (Bernard 2000) In 2002, the American Society for Testing and Materials (ASTM) issued test method C1550-02 "Standard Test Method for Flexural Toughness of Fiber-Reinforced Concrete (Using Centrally-Loaded Round Panels)".

The test uses a $\varnothing 800 \mathrm{~mm} \times 75 \mathrm{~mm}$ round panel which is supported on three ball bearings providing point like hinged supports at $\varnothing 750 \mathrm{~mm}$ (Fig. 1b). The panel is loaded centrally using hemispherically rounded $\varnothing 100 \mathrm{~mm}$ piston and the load-deflection curve is recorded until the deflection reaches $45 \mathrm{~mm}$.

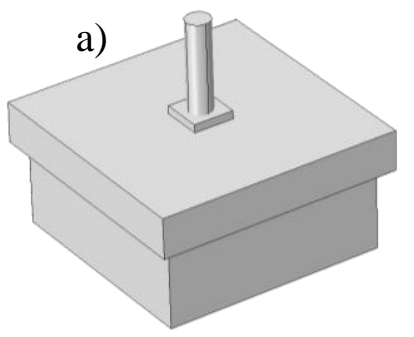

Figure 1a. EN 14488-5 slab

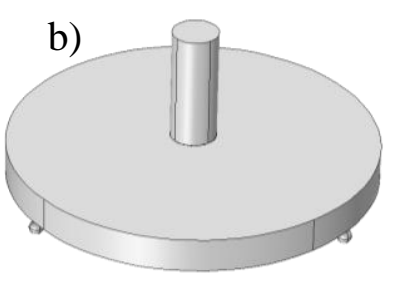

Figure 1b. ASTM C1550 panel

\section{MATERIALS AND METHODS}

\subsection{Design assumptions}

To use the simplified Yield-Line Theory we must make these design assumptions:

I The material is ideally plastic.

II The angles are small $\left(<0.176 \mathrm{rad}\right.$ or $\left.<10^{\circ}\right)$.

III Friction is ignored.

\subsection{Yield-line pattern}

The yield-line pattern can be chosen freely, as long as the following condition is not violated: The yieldline between two parts of a slab must pass through the intersection (Fig. 2a) of their axes of rotation (Johansen 1962). Freely supported edges will rotate, but fixed supports require an additional yield-line along the supports.

After the yield-line candidate has been chosen, the next step is to calculate the internal and external energies using the concept of virtual work. In this concept, we force an infinitesimal virtual displacement, typically at loading, to calculate the corresponding virtual internal and external work and finally require the sum of works to be zero to respect equilibrium and conservation of energy. In order to use the projection method (Fig. 2b), which produces a more elegant set of equations, we require that all the rotations must be in opposite directions over each yield-line.
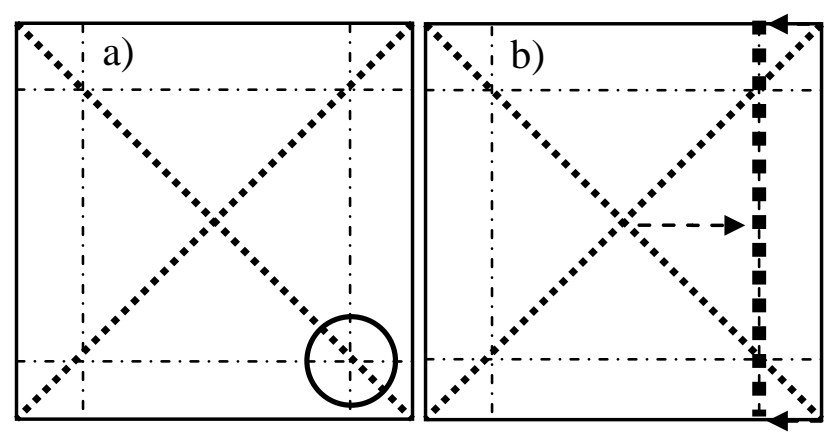

Figure 2. Yield-line (dotted) pattern intersecting (circle) the axes of rotation (dash-dot) (a). Projection (heavy dotted) of a yield-line along the axes of rotation (b).

For the ASTM C1550-12a type of panel test there is only one yield pattern, which always occurs on low to medium fibre dosages (Fig. 3). High fibre dosages in either panel type will lead to more elaborate patterns of higher energy absorption capacity.

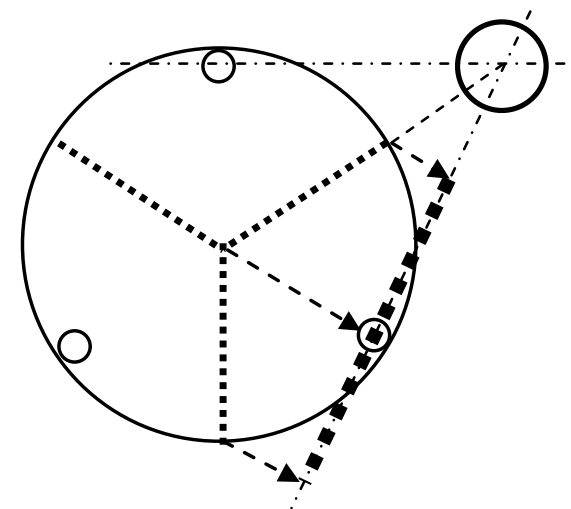

Figure 3. The yield-pattern (dotted) of C1550 round testing panel and the projected (heavy dotted) yield-line along axis of rotation (dash-dot). The extension (dashed) of the yield-line intersects (circle) the crossing of the two rotation axes.

The yield-line pattern may also be parameterized to find a solution, which corresponds to the least work. An example of this is shown in Figure 4, where a yield-pattern of two orthogonal yield-lines crossing in the center has been parameterized to allow for rotation of the pattern. 


\subsection{Virtual work}

The EN 14488-5:2006 does not specify that corner uplift should be suppressed. The internal virtual work is the moment multiplied by the virtual rotation over the total length of projected yield-line along the rotation axes. Using parametrical representation (Fig. 4) it can be shown that any orthogonal pattern will result in the same internal work of

$W_{\text {int, } E N}=-9.6 m_{E N} \delta$,

where $m_{E N}=$ moment over the rotation line and $\delta=$ virtual displacement. The external virtual work is the load multiplied over the virtual distance traveled

$W_{\text {ext }}, E N=F \delta$.

The sum of virtual work must be zero and for any EN slab with orthogonal yield pattern the failure load is

$$
F_{E N}=9.6 m_{E N} \cdot
$$

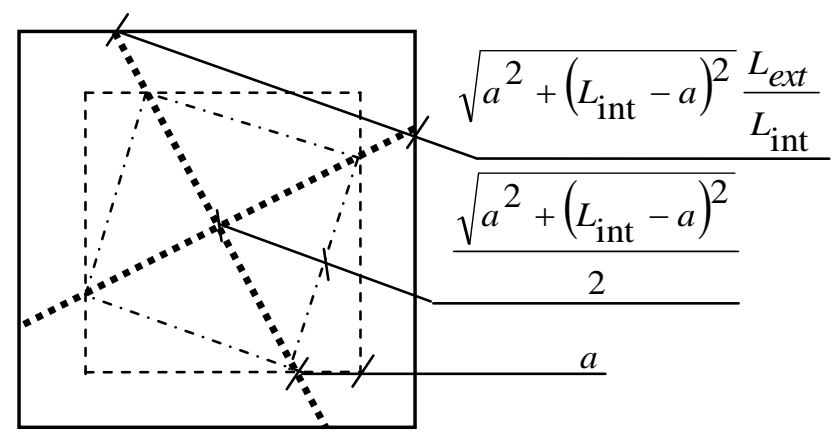

Figure 4. Parameterized orthogonal cross type yield-pattern (dotted) of a continuously supported (dashed) square slab. $L_{\text {ext }}$ is the width of the slab, $L_{\text {int }}$ the internal width of the continuous support and $a$ is the free parameter.

For the $\mathrm{C} 1550$ panel the equations become

$W_{\text {int, }} C 1550=-3 \sqrt{3} m_{C 1550} \delta$,

$W_{\text {ext }}, C 1550=F \delta$,

$$
F_{C 1550}=3 \sqrt{3} m_{C 1550} \text {. }
$$

Due to a difference in slab height, the equations cannot be directly compared. The following conversion equations compensate for the height difference

$$
\begin{aligned}
& F_{E N}=9.6 m_{E N} \approx 17 m_{C 1550} \approx 3.2 F_{C 1550}, \\
& F_{C 1550} \approx 5.2 m_{C 1550} \approx 2.9 m_{E N} \approx 0.31 F_{E N} .
\end{aligned}
$$

\subsection{Bending moment}

Using the Equations 7 and 8 requires the bending moment, which can be calculated using the ideally elastic model (cracking initiation or ultimate brittle load) or using the ideally elastic-plastic model (ultimate ductile load). A yield-line will behave elastically (Fig. 5a) until the tensile strength is reached and the first large cracks open. Depending on the fiber amount the yield-line will then follow a cracked brittle residual state (Fig. 5b) or cracked ductile residual state (Fig. 5c). Ideally plastic joint (Fig. 5d) can be used as an upper bound estimate to the ductile state and the uncracked state is the upper bound estimate for brittle residual state.

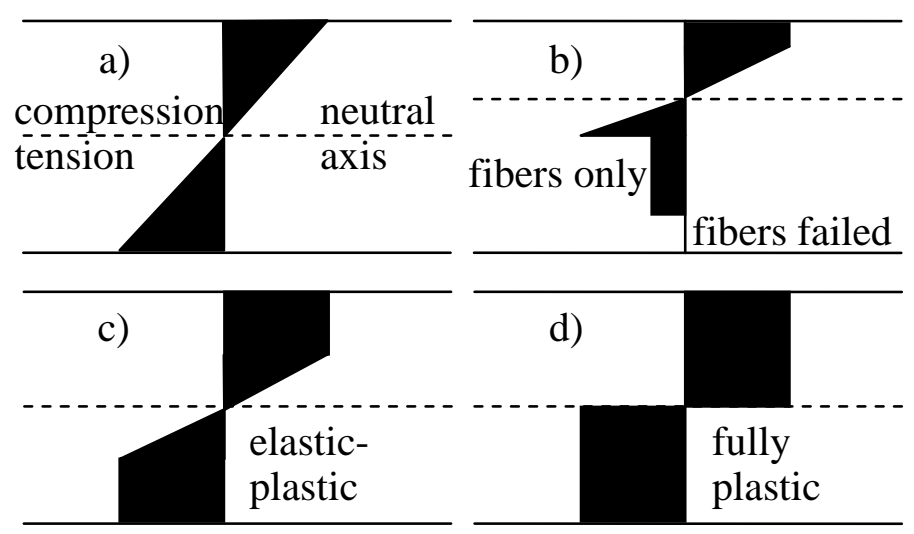

Figure 5. Uncracked initial state (a). Cracked brittle residual state (b). Cracked ductile residual state (c). Ideally plastic joint (d).

The cracking moment of sprayed concrete can be calculated using elastic theory as

$m_{e l}=\frac{f_{t, f l} h^{2}}{6}$,

where $f_{t, f l}=$ flexural tensile strength; $h=$ slab thickness. The plastic moment is $50 \%$ greater

$m_{p l}=\frac{f_{t, f l} h^{2}}{4}$.

\subsection{Flexural tensile strength}

The flexural tensile strength can be calculated using the equations presented in the Eurocode 2 (EN 19921-1:2004). Mean value of axial tensile strength of concrete can be derived from the compressive cylinder strength

$$
\begin{aligned}
& f_{c k} \leq 50 \mathrm{MPa} \rightarrow f_{c t m}=0.30 f_{c k} \frac{2}{3}, \\
& f_{c k}>50 \mathrm{MPa} \rightarrow f_{c t m}=2.12 \ln \left(1+\frac{f_{c k}+8}{10}\right),
\end{aligned}
$$


where $f_{c k}=$ characteristic compressive cylinder strength of concrete at 28 days in MPa. The characteristic (5\% fractile) value can be derived from the mean strength

$f_{c t k, 0.05}=0.7 f_{c t m}$.

The flexural tensile strengths are

$$
\begin{aligned}
& f_{c t m, f l}=\max \left\{\left(1.6-\frac{h}{1000}\right) f_{c t m} ; f_{c t m}\right\}, \\
& f_{c t k, 0.05, f l}=\max \left\{\left(1.6-\frac{h}{1000}\right) f_{c t k, 0.05} ; f_{c t k, 0.05}\right\} .
\end{aligned}
$$

\subsection{Flexural tensile resistance (upper bound)}

Combining the presented equations, the mean ultimate elastic resistances are

$$
\begin{aligned}
& R_{E N, e l}=7200 \mathrm{~mm}^{2} f_{c k} \frac{2}{3}, \\
& R_{C 1550, e l} \approx 2230 \mathrm{~mm}^{2} f_{c k} \frac{2}{3}
\end{aligned}
$$

The corresponding characteristic responses are 0.7 times the mean values and the plastic responses are 1.5 times the elastic responses.

It should be noted that the elastic approach is problematic: The yield-line theory assumes that the entire yield-line has exceeded the elastic resistance and remains in the yielding plastic region. The elastic resistance cannot be simultaneously reached along the yield-lines due to the kinematic restrictions. The elastic approach should be used with caution.

\subsection{Flexural tensile resistance (lower bound)}

The linear elastic theory can be used to determine the lower bound resistance at the moment when the cracking moment capacity is reached. The following equations were derived using COMSOL Multiphysics 4.3a Solid Mechanics (no corner uplift)

$$
\begin{aligned}
& R_{E N, e l} \approx 3710 \mathrm{~mm}^{2} f_{c k} \frac{2}{3}, \\
& R_{C 1550, e l} \approx 1570 \mathrm{~mm}^{2} f_{c k} \frac{2}{3} .
\end{aligned}
$$

\section{RESULTS}

\subsection{Disclaimer}

The values presented in this paper are characteristic (5\% fractile) and mean upper bound values and should not be used directly in design. To use the results in design, follow the design norms which are valid in your geographical region. The results lack a rigorous and extensive verification series (2013). To obtain design values, use the nationally defined parameters, which have been defined of your country for the safety factors.

Note that these results are calculated based on the concrete properties only. Fibres may increase the cracking tensile resistance. If the concrete axial or flexural tensile strength has been measured, the measured value should be used for better accuracy. If the concrete compressive strength has been measured, it can be used to derive more accurate strength parameters.

\subsection{Prediction}

After the concrete strength class has been defined, the bending resistance can be calculated. Summary of results for the most common concrete grades are shown in Tables $1 \& 2$. These values are upper bound estimates.

Table 1. Elastic flexural tensile resistance

\begin{tabular}{llllll}
\hline Concrete Grade & \multicolumn{2}{l}{ EN 14488-5 } & & \multicolumn{2}{c}{ ASTM C1550 } \\
\cline { 2 - 3 } \cline { 5 - 6 }$f_{c k} / f_{c k, c u b e}$ & $5 \%$ & mean & & $5 \%$ & mean \\
{$[\mathrm{MPa}] /[\mathrm{MPa}]$} & {$[\mathrm{kN}]$} & {$[\mathrm{kN}]$} & & {$[\mathrm{kN}]$} & {$[\mathrm{kN}]$} \\
\hline $\mathrm{C} 20 / 25$ & 27.1 & 53.1 & & 11.5 & 16.4 \\
$\mathrm{C} 25 / 30$ & 43.1 & 61.6 & & 13.3 & 19.1 \\
$\mathrm{C} 30 / 37$ & 48.7 & 69.5 & & 15.1 & 21.5 \\
$\mathrm{C} 35 / 45$ & 53.9 & 77.0 & & 16.7 & 23.9 \\
$\mathrm{C} 40 / 50$ & 58.9 & 84.2 & & 18.3 & 26.1 \\
$\mathrm{C} 45 / 55$ & 63.8 & 91.1 & & 19.7 & 28.2 \\
$\mathrm{C} 50 / 60$ & 68.4 & 97.7 & & 21.2 & 30.3 \\
\hline
\end{tabular}

Table 2. Plastic flexural tensile resistance

\begin{tabular}{llllll}
\hline Concrete Grade & \multicolumn{2}{l}{ EN 14488-5 } & & \multicolumn{2}{c}{ ASTM C1550 } \\
\cline { 2 - 3 }$f_{c k} / f_{c k, c u b e}$ & $5 \%$ & mean & & $5 \%$ & mean \\
{$[\mathrm{MPa}] /[\mathrm{MPa}]$} & {$[\mathrm{kN}]$} & {$[\mathrm{kN}]$} & & {$[\mathrm{kN}]$} & {$[\mathrm{kN}]$} \\
\hline $\mathrm{C} 20 / 25$ & 55.7 & 79.6 & & 17.3 & 24.6 \\
$\mathrm{C} 25 / 30$ & 64.6 & 92.3 & & 20.0 & 28.6 \\
$\mathrm{C} 30 / 37$ & 73.0 & 104.3 & & 22.6 & 32.3 \\
$\mathrm{C} 35 / 45$ & 80.9 & 115.6 & & 25.1 & 35.8 \\
$\mathrm{C} 40 / 50$ & 88.4 & 126.3 & & 27.4 & 39.1 \\
$\mathrm{C} 45 / 55$ & 95.6 & 136.6 & & 29.6 & 42.3 \\
$\mathrm{C} 50 / 60$ & 102.6 & 146.6 & & 31.8 & 45.4 \\
\hline
\end{tabular}

\subsection{Observation}

When the slab tests have been carried out, the first crack load and the ultimate load may be used to back-calculate the true concrete strengths (Tables 3 \& 4). 
Table 3. Elastic tensile strength for EN 14488-5

\begin{tabular}{|c|c|c|c|c|}
\hline \multirow{2}{*}{$\begin{array}{l}\text { EN } 14488-5 \\
\text { observed mean } \\
\text { first crack }[\mathrm{kN}]\end{array}$} & \multicolumn{2}{|c|}{ flexural $f_{c t m, f l}$} & \multicolumn{2}{|c|}{ tensile $f_{c t m}$} \\
\hline & $\begin{array}{l}5 \% \\
{[\mathrm{MPa}]}\end{array}$ & $\begin{array}{l}\text { mean } \\
{[\mathrm{MPa}]}\end{array}$ & $\begin{array}{l}5 \% \\
{[\mathrm{MPa}]}\end{array}$ & $\begin{array}{l}\text { mean } \\
{[\mathrm{MPa}]}\end{array}$ \\
\hline 50 & 2.2 & 3.1 & 1.5 & 2.1 \\
\hline 55 & 2.4 & 3.4 & 1.6 & 2.3 \\
\hline 60 & 2.6 & 3.8 & 1.8 & 2.5 \\
\hline 65 & 2.8 & 4.1 & 1.9 & 2.7 \\
\hline 70 & 3.1 & 4.4 & 2.0 & 2.9 \\
\hline 75 & 3.3 & 4.7 & 2.2 & 3.1 \\
\hline 80 & 3.5 & 5.0 & 2.3 & 3.3 \\
\hline
\end{tabular}

Table 4. Elastic tensile strength for ASTM C1550

\begin{tabular}{|c|c|c|c|c|}
\hline \multirow{2}{*}{$\begin{array}{l}\text { ASTM C1550 } \\
\text { observed mean } \\
\text { first crack [kN] }\end{array}$} & \multicolumn{2}{|c|}{ flexural $f_{c t m, f l}$} & \multicolumn{2}{|c|}{ tensile $f_{c t m}$} \\
\hline & $\begin{array}{l}5 \% \\
{[\mathrm{MPa}]}\end{array}$ & $\begin{array}{l}\text { mean } \\
{[\mathrm{MPa}]}\end{array}$ & $\begin{array}{l}5 \% \\
\text { [MPa] }\end{array}$ & $\begin{array}{l}\text { mean } \\
{[\mathrm{MPa}]}\end{array}$ \\
\hline 16 & 2.3 & 3.3 & 1.5 & 2.2 \\
\hline 18 & 2.6 & 3.7 & 1.7 & 2.4 \\
\hline 20 & 2.9 & 4.1 & 1.9 & 2.7 \\
\hline 22 & 3.2 & 4.5 & 2.1 & 3.0 \\
\hline 24 & 3.4 & 4.9 & 2.3 & 3.2 \\
\hline 26 & 3.7 & 5.3 & 2.4 & 3.5 \\
\hline 28 & 4.0 & 5.7 & 2.6 & 3.8 \\
\hline
\end{tabular}

\subsection{Comparison}

This comparison data comes from Länsimetro westbound metro extension of Helsinki in Finland. The sprayed concrete grade was specified as C35/45, but the actual measured strengths were higher and averaged at $C 45 / 55$. The results are shown in Tables 5 (steel fibres) and 6 (polymer fibres).

Table 5. Länsimetro data (steel fibres)

\begin{tabular}{|c|c|c|c|c|c|}
\hline \multicolumn{2}{|c|}{ Testing report } & \multirow{2}{*}{$\begin{array}{l}\text { strength } \\
\mathrm{f}_{\mathrm{ck}} \\
{[\mathrm{MPa}]}\end{array}$} & \multirow{2}{*}{$\begin{array}{l}\text { cracking } \\
\mathrm{R}_{\mathrm{c}} \\
{[\mathrm{kN}]}\end{array}$} & \multirow{2}{*}{$\begin{array}{l}\text { ultimate } \\
\mathrm{R}_{\mathrm{u}} \\
{[\mathrm{kN}]}\end{array}$} & \multirow{2}{*}{$\begin{array}{l}\frac{\text { energy }}{E_{25 \mathrm{~mm}}} \\
{[\mathrm{~J}]}\end{array}$} \\
\hline & $\mathrm{n}$ & & & & \\
\hline B-9741 ${ }^{(1)}$ & 6 & $*$ & 43.7 & 61.1 & 1190 \\
\hline C-1753 $3^{(2)}$ & 4 & 49.9 & 66.0 & 89.3 & 1260 \\
\hline $\mathrm{C}-0812^{(3)}$ & 4 & 39.4 & 53.0 & 80.3 & 1610 \\
\hline $\mathrm{B}-8785^{(3)}$ & 5 & 47.1 & 66.5 & 95.4 & 1580 \\
\hline \multirow[t]{2}{*}{ B-9089 (3) } & 3 & 51.7 & 56.0 & 70.6 & 1415 \\
\hline & 22 & 46.7 & 56.3 & 78.8 & 1400 \\
\hline
\end{tabular}

Table 6. Länsimetro data (polymer fibres)

\begin{tabular}{|c|c|c|c|c|c|}
\hline Testing re & port & strength & cracking & ultimate & energy \\
\hline & $\mathrm{n}$ & $\begin{array}{l}\mathrm{f}_{\mathrm{ck}} \\
{[\mathrm{MPa}]}\end{array}$ & $\begin{array}{l}\mathrm{R}_{\mathrm{c}} \\
{[\mathrm{kN}]}\end{array}$ & $\begin{array}{l}\mathrm{R}_{\mathrm{u}} \\
{[\mathrm{kN}]}\end{array}$ & $\begin{array}{l}\mathrm{E}_{25 \mathrm{~mm}} \\
{[\mathrm{~J}]}\end{array}$ \\
\hline C-2998 ${ }^{(1)}$ & 4 & 37.6 & 55.0 & 64.8 & 1320 \\
\hline C-3002 $2^{(2)}$ & 4 & 37.6 & 48.1 & 66.3 & 1380 \\
\hline C-0301 $1^{(2)}$ & 4 & 36.8 & 43.1 & 65.1 & 1280 \\
\hline C- $1622^{(3)}$ & 6 & 48.1 & 42.8 & 58.9 & 1170 \\
\hline C- $0717^{(3)}$ & 6 & 53.5 & 46.1 & 72.3 & 1460 \\
\hline C- $1745^{(4)}$ & 5 & 45.4 & 50.2 & 58.3 & 1220 \\
\hline C- $0530^{(4)}$ & 4 & 39.1 & 43.8 & 59.6 & 1240 \\
\hline & 36 & 43.7 & 46.8 & 63.7 & 1300 \\
\hline
\end{tabular}

\section{CONCLUSIONS}

\subsection{Yield-line theory models}

This paper presents the plastic upper bound bending resistances of the EN 14488-5 (Eq. 16) and ASTM C1550 (Eq. 17) panel tests and provides the conversion equations between the tests (Eqs. $7 \& 8$ ). The EN 14488-5 requires a sketch or photograph of the cracks and the ASTM C1550 requires the number of radial cracks. This enables verification of corresponding yield-line pattern.

\subsection{Strength parameters for sprayed concrete}

Chapters 2.4, 2.5 and 2.6 present how the required concrete strength parameters can be derived from the specified strength grade. Tables $1 \& 2$ present the upper bound resistances based on concrete grade. The linear elastic lower bound mean resistances may be calculated using Equations 18 \& 19.

\subsection{Effect of fibres in sprayed concrete}

In Länsimetro, use of $60 \mathrm{~kg} / \mathrm{m}^{3}$ of steel fibres was required in safety shotcreting. This dosage produced $10 \mathrm{kN}(20 \%)$ stronger cracking resistances than using $7-8 \mathrm{~kg} / \mathrm{m}^{3}$ of polymer fibres. The ultimate resistances were $15 \mathrm{kN}(23 \%)$ stronger and the energy absorption was $100 \mathrm{~J}(8 \%)$ higher.

\section{DISCUSSION}

\subsection{Yield-line theory models}

The ASTM C1550 consistently produces the predicted yield pattern at low to medium fibre dosages. High fibre dosage will lead to more elaborate patterns, which have higher internal energies and can be calculated using yield-line theory when the pattern corresponds to the failure mode. The EN 14488-5 is less robust and usually produces a number of yield-lines intersecting the load point.

\subsection{Strength parameters for sprayed concrete}

When compared to quality assurance measurements from rock engineering projects in Finland, the material parameter equations presented in the concrete Eurocode (EN 1992-1-1:2004) work reasonably well. In Länsimetro project, the specified compressive strength is always exceeded. This might be influenced by the high cement amount and the usage of silica.

\subsection{Effect of fibres in sprayed concrete}

Fibres redistribute drying shrinkage cracks and may increase the first crack strength slightly by 
homogenizing the crack distribution. The fibres resist expansion of the concrete under compression. They are strong enough to hold poor adhesion concrete from falling and will keep damaged pieces of concrete together. After the initial cracking, the residual states are quite weak and do not reach the cracking load at low to normal fibre dosages.

When a significant amount of fibres is added, the mechanical behaviour of the concrete can be improved. If the fibre reinforced sprayed concrete has enough residual tensile strength, the residual state can climb back to the cracking load and even exceed it. In very strong sprayed concretes, the behaviour becomes elastic-plastic. In Länsimetro project, this was observed by the lack of drops in load bearing capacity after cracks and a smoother transition from elastic region to plastic region.

\subsection{Dynamic and static actions}

Dynamic actions include squeezing ground, impacts and energetic rock bursts. Sprayed concrete for these scenarios can be designed using the total energy approach and the energy classes E500, E700, E1000 presented in EN 14487-1:2005 corresponding to a deflection of $25 \mathrm{~mm}$. Using the ASTM C1550 test, the energies are normally obtained from the $5 \mathrm{~mm}$, $10 \mathrm{~mm}, 20 \mathrm{~mm}$ or $40 \mathrm{~mm}$ deflections, depending on application.

Static actions occur when the load varies little or not at all. One example is a hard rock block loading a thin sprayed concrete lining. In static cases, the energy classes become meaningless as the resistance only depends on the ultimate load resistance of the concrete lining. If water-tightness or durability requirements have been set, it may be more appropriate to require cracking resistance instead.

\section{ACKNOWLEDGEMENTS}

The authors thank Jarkko Niiranen (Aalto University) and Djebar Baroudi (Aalto University) for helpful discussions concerning the structural mechanics involved. We thank Matti Kokkinen (Länsimetro $\mathrm{Oy}$ ) for permitting the use of Länsimetro project shotcrete quality assurance data. We thank Jesse Ström (Rockplan) for extracting and compiling the data.

\section{REFERENCES}

ASTM C1550-02, Standard Test Method for Flexural Toughness of Fiber Reinforced Concrete (Using Centrally Loaded Round Panel). West Conshohocken: ASTM Int'l.

ASTM C1550-12a, Standard Test Method for Flexural Toughness of Fiber Reinforced Concrete (Using Centrally Loaded Round Panel). West Conshohocken: ASTM Int'l.
Bernard, E.S. 2000, Behavior of Round Steel Fiber Reinforced Concrete Panels under Point Loads. Materials and Structures. 33: 181-188.

Braestrup, M.W. 2007, Yield line theory and concrete plasticity, Morley Symposium on Concrete Plasticity and its Application., University of Cambridge.

EFNARC 1999. European specification for sprayed concrete: Guidelines for specifiers and contractors, Surrey: EFNARC

EN 206-1:2000. Concrete - Part 1: Specification, performance, production and conformity. Brussels: CEN.

EN 1992-1-1: 2004. Eurocode 2: Design of concrete structures - Part 1-1: General rules and rules for buildings. Brussels: CEN.

EN 14487-1:2005. Sprayed concrete. Part 1: Definitions, specifications and conformity. Brussels: CEN.

EN 14488-5:2006. Testing sprayed concrete. Part 5: Determination of energy absorption capacity of fibre reinforced concrete slab specimens. Brussels: CEN

Holmgren, J. 1993. The use of yield-line theory in design of steel-fibre reinforced concrete slabs in Shotcrete for Underground Support IV. New York: American Society of Civil Engineers.

Ingerslev, A. 1921. Om en elementær beregningsmetode af krydsarmerede plader (On a Simple Analysis of Two-Way Slabs). Ingeniфren, 30, 69: 507-515.

Johansen, K.W. 1931. Beregning af kryd sarmerede jernbetonpladers brudmoment, Bygningsstatiske Meddelelser, 3, 1: 1-18.

Johansen, K.W. 1943. Brudlinietheorier (Yield-line theory). Kopenhagen: DTH Lyngby.

Johansen, K.W. 1962. Yield-line theory. London: Cement and Concrete Association.

Johansen, K.W. 1972. Yield-Line Formulae for Slabs. London: Cement and Concrete Association. 